\title{
Marine zooplankton studies in Brazil - A brief evaluation and perspectives
}

\author{
RUBENS M. LOPES \\ Departamento de Oceanografia Biológica, Instituto Oceanográfico, Universidade de São Paulo \\ Praça do Oceanográfico, 191, Cidade Universitária, 05508-900 São Paulo, SP, Brasil \\ Manuscript received on September 11, 2006; accepted for publication on March 28, 2007; \\ presented by LUCIA MENDONÇA PREVIATO
}

\begin{abstract}
Marine zooplankton research in Brazil has been primarily descriptive, with most studies focusing on community structure analysis and related issues. The composition and spatial distribution of several taxonomic groups are currently well known, although less-abundant and small-sized taxa as well as initial stages of almost all species have received little attention. Some numerically important taxa such as heterotrophic protists, ctenophores, acoel turbellarians and ostracods remain virtually unstudied. Large sectors of the continental shelf have not been sampled in detail, particularly those areas influenced by the North Brazil Current $\left(5^{\circ} \mathrm{N}-15^{\circ} \mathrm{S}\right)$. Zooplankton abundance and biomass in offshore waters have seldom been quantified, and information on the distribution and vertical migration of meso- and bathypelagic species are lacking. Additional faunistic assessments must target those less-studied taxa and geographical locations. However, priority in ecological studies should be given to process-oriented investigations aimed at understanding the mechanisms controlling zooplankton distribution, trophic interactions within pelagic food webs and production cycles in relation to the physical environment. An effort should be made to incorporate state-of-the-art sampling technology and analytical methods into future research projects.
\end{abstract}

Key words: marine zooplankton, ecology, taxonomy, Southwest Atlantic.

\section{INTRODUCTION}

Most marine animal phyla - from poriferans to chordates - are represented in the plankton. Many species are holoplanktonic, i.e., they live permanently in the pelagic habitat. Other taxa are meroplanktonic, and are found in the plankton realm only as eggs and larvae, while the adult stages integrate the benthos or the nekton. The reproductive strategy of several holoplanktonic species involves, however, a benthic phase in the form of resting cysts or eggs, which are produced when environmental conditions become adverse. Various groups of heterotrophic protists are also represented in the marine plankton and make up the so-called protozooplankton. Many physical and chemical parameters influence zooplankton abundance and distribution, with direct (reten-

E-mail: rmlopes@usp.br tion, advection, mortality) and indirect (food availability, predation, competition for space or resources) effects on the secondary productivity of coastal and oceanic ecosystems (Miller 2004). The study of marine zooplankton ecology thus demands considerable efforts from the scientific and technological standpoint, given the great variety of taxonomic groups, size classes and life cycle strategies found in this group of organisms.

New paradigms on the role of planktonic communities in marine ecosystems have emerged in the past twenty years, with the acceleration of technological development applied to biological oceanography and the implementation of several international research programs, such as JGOFS (Joint Global Ocean Flux Study) and GLOBEC (Global Ecosystem Dynamics). One of the significant findings of JGOFS is the existence of a strong linkage between marine zooplankton metabolic 
activity and the transfer of atmospheric carbon into the deep ocean, with significant consequences for global climate (Ducklow and Steinberg 2001). The ongoing GLOBEC project tackles the physical environmental forcing of zooplankton and fish productivity, in a successful endeavor to cope with different analytical scales including those relevant to human systems (Perry and Ommer 2003). A newly established international research program, the IGBP-SCOR "Integrated Marine Biogeochemistry and Ecosystem Research", will pursue details of ocean biogeochemical cycles and their coupling with ecosystem functioning at various trophic levels, giving a strong emphasis on microbe, zooplankton and fish interactions (IMBER 2005).

How deeply is marine zooplankton research in Brazil embedded into this worldwide scenario of scientific and technological advances? To answer this question, it is necessary to evaluate the scientific developments achieved to date in this field of investigation, in order to identify the major gaps and challenges that must be tackled in upcoming years. Such exercise is the major objective of the present paper, which, however, does not intent to provide a comprehensive review of the literature. Readers must refer to Brandini et al. (1997) and Lopes et al. (2006a) for full publication lists on marine zooplankton off Brazil. The following text focuses on coastal and oceanic zooplankton, and does not emphasize research in estuarine systems.

\section{DESCRIPTIVE STUDIES - ZOOPLANKTON COMPOSITION, ABUNDANCE AND DISTRIBUTION}

The study of the taxonomy and distribution of marine zooplankton in Brazil started in the $19^{\text {th }}$ century, through sporadic sampling performed during the first international oceanographic expeditions. In the early $20^{\text {th }}$ century, scientists at laboratories in southern and southeastern Brazil started to perform general faunistic assessments, but it was only from the 1950s on that research groups were established on a more permanent basis in universities and other institutions in the country (Brandini et al. 1997, Lopes et al. 2006a). As a result, studies on zooplankton composition and distribution started to flourish only after that decade (Fig. 1).

Descriptive analysis of the structure of zooplanktonic associations was the main focus of investigations initially performed in Brazil. However, the same approach predominates today, after more than fifty years, because most publications released in the past decades deals with the analysis of zooplankton specific composition, numerical density and spatial distribution in relation to the predominant water masses. Such research focus brought much useful information. For instance, it is currently not difficult to predict which dominant species may be found in a given sector of the continental shelf with definite thermohaline characteristics, especially on the South and Southeast coasts, for which more information exists (Brandini et al. 1997). Nonetheless, the excessive emphasis on "distributional" studies together with the virtual absence of process-oriented investigations during the last century have clearly hampered our ability to understand the role of planktonic food webs in marine ecosystems off Brazil.

The majority of investigations carried out since 1960 have dealt specifically with pelagic copepods, followed by more general surveys on zooplankton composition and distribution which, in turn, focused on copepods again as the numerically dominant taxon (Fig. 1). Other zooplankton groups such as hydromedusae, mysids, siphonophorans and cladocerans are relatively well known in the region, but the number of publications decreases exponentially toward the lessinvestigated taxa (Fig. 2).

Therefore, even after several decades of study, we still know very little on the occurrence and distribution of many important zooplankton taxonomic groups. This is the case of most heterotrophic protists - especially the aloricate forms (cilliates, amoebas, zooflagellates) or those which do not preserve well in formaldehyde (acantharians, radiolarians) - and of certain metazoans which may reach high abundance levels in shelf waters. Among the latter may be cited the ctenophores, planktonic turbellarians and ostracods. Until recently, ctenophores were only briefly mentioned in few studies on the distribution of estuarine zooplankton (Lopes et al. 1986, Montú and Cordeiro 1988), although these organisms constitute an important group of pelagic predators in coastal regions (Mills 1995). Oliveira and Migotto (2006) published the first comprehensive assessment of ctenophore composition off Brazil. Some taxa mentioned above have been studied in detail in limited areas 

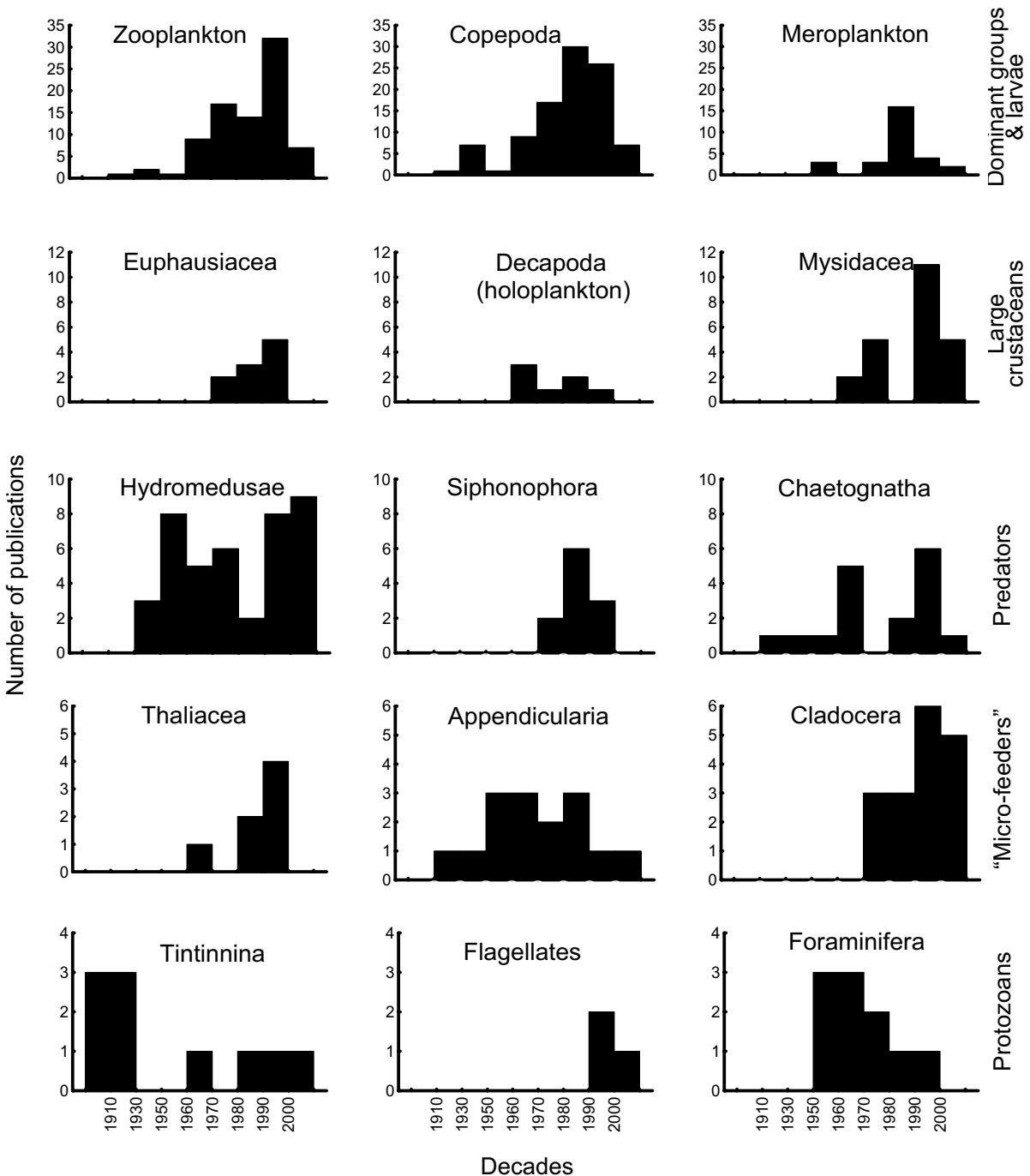

Fig. 1 - Decadal variation in the number of publications (theses included) on a range of marine zooplankton taxa in Brazil (south and southeast continental shelf). The category "Zooplankton" refers to studies dealing with the whole zooplankton community at varying degrees of taxonomic resolution. "Meroplankton" includes publications related to larval stages of benthic animals such as decapods, polychaetes and mollusks. Note the different scales on the ordinate axis for each category. Data from Lopes et al. (2006a).

of the São Paulo State coast (Rocha 1983, Lopes and Silveira 1994, Eskinazi-Sant' Anna 2006) and thus there is no information on their meso- or macroscale distribution on the continental shelf and in oceanic areas. Studies done in the Cabo Frio region off Rio de Janeiro State have revealed the numeric importance of ostracods, without however identifying them down to the species level (Valentin 1984, 1989).
It is also worth to mention that the processes determining the occurrence and spatial distribution of salps and other thaliaceans are barely known, even if Tavares (1967), Bonecker (1983) and Katsuragawa et al. (1993) have provided important preliminary results. The negative influence of salp aggregations on non-gelatinous plankton, as suggested in those works, may be related to the direct competition for algal food or to production of 


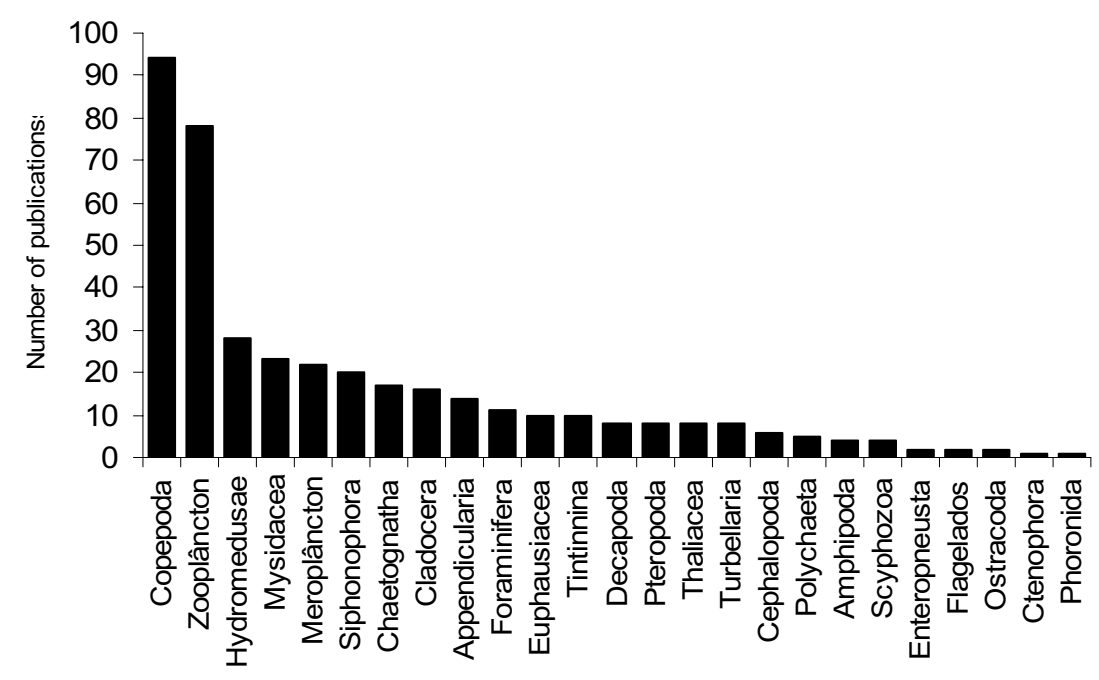

Fig. 2 - Total number of publications (theses included) on several marine zooplankton groups investigated in Brazilian waters (south and southeast continental shelf) since the beginning of the $20^{\text {th }}$ century. Data from Lopes et al. (2006a).

toxic substances by salps (Folt and Goldman 1981), but such cause-effect relationship has not been established in Brazilian waters so far.

Also, little is known on the ecology of larval and juvenile stages of holoplanktonic groups for which spatial distribution of adults is reasonably well studied (good examples being copepod nauplii and euphausid larvae). The specific composition and distribution of meroplankton has not been studied in detail, exception made to a few estuarine and inshore investigations (Veloso and Valentin 1993, Schwamborn and Bonecker 1996, Freire 2003, Koettker and Freire 2006), which account for the relatively high number of publications depicted in Figure 1.

Therefore, a series of gaps exists that fully supports, from the taxonomic standpoint, the development of descriptive studies of marine zooplankton on the Brazilian coast, as long as priority is given to the up-to-now little studied groups, or to those requiring revision to elucidate systematic and distributional aspects (see also Migotto and Marques 2003). A fine example of the latter is the global phylogenetic study of a well-known pelagic copepod family, the Eucalanidae, performed by Goetze (2003) through an approach with potential applications in a more regional context.
There are sectors of the Brazilian continental shelf where quantitative analyses of zooplankton distribution are scarce. This applies not only to the large neritic sector north of Cabo de São Tomé, but also to some areas on the South-Southeast coast, such as off Paraná and Santa Catarina States. But whatever the region considered, studies on zooplankton distribution have been mostly based on sampling strategies of low spatial resolution, with oceanographic stations several nautical miles apart. In addition to the low horizontal detailing afforded by this kind of sampling, few expeditions collected zooplankton at different strata along the water column. The only data of this kind come from samples obtained with regular closing nets, which allow for few hauls at the same station, and these usually afford low precision in terms of vertical positioning and estimation of filtered volume. Several studies yielded useful data on vertical zooplankton distribution but these were generally derived from one sampling station, obviously compromising the horizontal resolution (e.g., Moreira 1976, Rocha 1982, Sinque 1983, Alvarez 1985).

For technical or operational reasons, most research projects on marine zooplankton along the Brazilian coast (especially from the intermediate shelf to offshore areas) were based on a single annual sampling or on sea- 
sonal collections, i.e. up to 4 cruises in a 1 -year interval (e.g., Lopes et al. 1999). Studies on zooplankton temporal variation which included monthly or quarterly sampling schemes were done at fixed stations close to the shore, and dealt with restricted taxonomic groups (Milstein 1979, Pinese 1982, Moreira et al. 1983). In addition, most of those studies did not analyze important environmental covariables, such as chlorophyll- $a$ concentration. The few exceptions to this approach were the studies on zooplankton temporal succession in the Cabo Frio upwelling system (Valentin 1980, 1989, Valentin et al. 1987), in the São Sebastião Channel (EskinaziSant'Anna and Björnberg 2006a, b) and on the inner shelf off Paraná (Sartori and Lopes 2000); yet the approach is hardly needed in those regions as well.

One of the consequences of the low spatial and temporal resolution of zooplankton sampling off Brazil has been our unawareness about the ontogenetic distribution and other key life cycle strategies of species associated with the South Atlantic Central Water (SACW) and the Tropical Water carried by the Brazil and North Brazil Currents. Little is yet known regarding the physicalbiological interactions related with the SACW intrusions or El Niño effects on the temporal variability and productivity of zooplankton in the region (Lopes et al. 2006b). Likewise, data are lacking on how natural or anthropogenic eutrophication influence the abundance and distribution of coastal zooplankton. These are some of the fundamental descriptive aspects for the understanding of the recruitment and maintenance of planktonic populations of great ecological and economic importance in the regional context.

The aforementioned methodological limitations also apply to studies on zooplankton biomass and production. Qualitative studies have been based on different methods of collection and analysis, rendering comparisons impossible in most cases. Most biomass data is expressed in terms of seston volume displacement, which become increasingly inexact in samples obtained from coastal waters, where particulate matter runoff from rivers, bays and lagoons is high. Another error resulting from the volume displacement method, producing an overestimation of values, occurs in the presence of gelatinous organisms such as medusae, siphonophores, ctenophores, salps and doliolids, which have much volume but little organic matter. An example are the high biovolume values recorded in the summer $\left(>8.0 \mathrm{~mL} \mathrm{~m}^{-3}\right)$ and spring $\left(>4.0 \mathrm{~mL} \mathrm{~m}^{-3}\right.$ ) of 1972 in southern Rio Grande do Sul State, where massive thaliacean aggregates were sampled in the euphotic layer (Navas-Pereira 1973). Even after manually excluding these gelatinous organisms from the samples prior to volume measurements, many small-sized individuals might still persist, causing an impact on estimates. More recent studies tend to estimate biomass through gravimetric methods (dry weight) of whole samples or aliquots and, in some cases, from direct and tedious sorting and subsequent weighting of individual species or taxonomic groups (Muxagata 1999). Morphometric techniques for the analysis of zooplanktonic biomass have been successfully applied in other tropical ecosystems (Hopcroft et al. 2001) and could be used more often in Brazilian waters due to the advantages they offer, such as: (i) determination of the biomass of individual genera or species, or even of species' developmental phases, (ii) possibility of microzooplankton biomass estimates, (iii) exclusion of detritus particles and phytoplankton from biomass measurements, and (iv) separate analysis of gelatinous zooplankton.

The dominance of autotrophic pico- and nanoplankton forms along the Brazilian coast (Teixeira and Gaeta 1991, Susini-Ribeiro 1999, Gaeta and Brandini 2006) is a strong indication that the micro- and nanozooplankton are key elements in the planktonic food web in the region. Yet studies on the abundance and biomass of protozooplankton and small metazooplankton are rare or even inexistent in Brazil, depending on the region considered. This can be explained at least partly by the use of large-mesh nets (usually $>300 \mu \mathrm{m}$ ) in most oceanographic cruises carried out to date.

The above limitations fully substantiate the development of descriptive studies on zooplankton abundance and distribution in oncoming years, as long as adequate sampling approaches are used. Some alternative strategies are listed at the end of this paper, which may be applied individually or combined to other techniques, according to the investigation plan and to logistic and financial possibilities. 


\section{PROCESS STUDIES - FEEDING, PRODUCTION AND OTHER ECOLOGICAL ASPECTS}

Knowledge on metabolic processes of the zooplankton community on the Brazilian coast is clearly not satisfactory, in spite of the advances verified in recent years. Zooplankton vital rates need to be estimated if we wish to understand biogeochemical processes and biological interactions at different levels of the pelagic food web. Qualitative or semi-quantitative aspects, such as gut content analysis (Liang and Vega-Perez 1995), are equally important. Studies on secondary production, metabolism (respiration, excretion and feeding, among others) and the trophic role of marine zooplankton represent priority lines of research for oncoming years.

A recent analysis of microzooplankton grazing off Rio de Janeiro coast has pointed out the importance of small-sized herbivores in controlling phytoplankton biomass and production under oligotrophic and mesotrophic conditions (McManus et al. 2007). However, additional experiments are needed to expand our knowledge on how physical forcing (e.g., upwelling or intrusion of nutrient-rich waters) affects the size structure of zooplankton and its relative contribution to the overall community grazing impact.

The combination of field and laboratory studies is surely a needed approach, but its validity depends on careful sampling, sorting and experimental planning. In situ determination of metabolic rates is a viable alternative to strict laboratory work, whenever the latter prove to be methodologically inadequate (Harbison and McAlister 1980, Roman and Rubble 1980). This question must be considered especially when the target organisms come from oceanic waters. These are the most sensitive to the confined environment of experimental containers and to changes in the physico-chemical quality of the water. A similar problem occurs with fragile organisms that may be easily damaged during collection and sorting, as is the case with gelatinous plankton and with species possessing extensive and fragile setae or other appendages.

Similarly to studies on zooplanktonic community structure, estimates of process rates must be obtained at spatial and temporal scales relevant to understanding interactions among planktonic organisms, and between these and the physical environment. Obviously, experi- mental planning must take into account the natural variability of environmental factors that influence the biological processes under investigation.

The methodological implications of this apparently obvious issue may be exemplified by the available alternatives for the study of zooplankton secondary production. Secondary production is estimated from animal biomass measurements and from growth (and, in certain cases, mortality) rates of the populations analyzed. Biomass is easy to measure, but the same cannot be said of growth and mortality rates. Traditional techniques developed to measure these rates, such as cohort analysis and cumulative growth studies (Bougis 1974, Rigler and Downing 1984), are based on the collection of data at short sampling intervals and along one or more generations. This constrains their application to determine instantaneous production rates in oceanic and shelf environments (due to the limited duration of oceanographic cruises), as well as in tropical regions, where planktonic species go through their entire life cycle in a few days. Besides, the behavior of most marine zooplankton populations does not adhere to the assumptions of cohort analysis (Kimmerer 1987).

Techniques that may yield more adequate measurements in both space and time scales include the artificial cohort technique (Kimmerer and McKinnon 1987), the egg-production rate method (Poulet et al. 1995) and the physiological method (Le Borgne 1982). The use of enzymatic analysis and molecular biology techniques has proven promising for the determination of copepod secondary production, but some methodological issues await resolution before these techniques may be considered universally applicable (Sapienza and Mague 1979, Roff et al. 1994, Bergeron 1995, Saiz et al. 1998, Oosterhuis et al. 2000).

Predictive models have been applied to derive zooplankton secondary production from more easily measured environmental variables such as temperature (Huntley and Lopez 1992). In this case, however, the resulting food-saturated rates usually overestimate zooplankton growth at any given temperature because natural populations are frequently food-limited, even in coastal regions subjected to intermittent pulses of nutrients and phytoplankton. Similar methodological problems are found when growth is calculated using empiri- 
cal equations relating metabolic rates to water temperature and biomass (Ikeda and Motoda 1978, Ikeda 1985, Hirst and Lampitt 1998), although the latter component is under certain circumstances a good proxy for food availability. The limitations of these methods probably arise from their bias toward data from food-rich environments. A more recent empirical model based on multiple regression analysis suggests that chlorophyll a concentration is a good proxy to predict copepod weight-specific fecundity and growth rates at high resolution over large areas of the ocean (Hirst and Bunker 2003). Predictions made through this model fall between 0.5 to 2 times the measured values obtained from the literature, which represents a significant improvement compared to previous modeling efforts. In any circumstances, due caution must be exercised when interpreting results obtained through indirect models, because the resulting secondary production rates may not account for variability in non-algal food supply or - even worst - may simply disregard food availability as an important environmental control of zooplanktonic populations. An example of the disparity between results obtained from direct and indirect methods may be found in the comparative work of Hay (1995) on copepod secondary production in the North Sea.

\section{SOME RECOMMENDATIONS FOR FUTURE WORK}

A summary of practical methodological suggestions for future studies follows below.

\section{- Use of zooplankton sampling devices at several} depth strata of the water column or through continuous profiles - The recommended standard procedure for sampling meso- and macrozooplankton on the continental shelf beyond the $20-\mathrm{m}$ isobath is through the use of multiple opening-closing net systems (such as the Multinet or MOCNESS), choosing the depth strata by preliminary evaluation of the local hydrography (CTD, fluorescence profiling etc.). Suction pumps may be used for better-resolution vertical samplings, but are quantitatively restricted to smaller plankters. Optical (LOPC) or acoustic (ADCP) recorders, video cameras and other imagecapture devices are the best option currently available for continous profiling, when combined with multiple net tows.
- Sampling on adequate horizontal scales - Sampling the horizontal zooplankton distribution in scales of meters to a few kilometers is necessary, especially in regions of unique hydrography, as in the case of estuarine plumes, eddies, gyres and shelf-break upwelling areas. This approach, combined with the analysis of vertical distribution following the above-mentioned procedures, would constitute an important step towards understanding the processes governing zooplankton spatial distribution on the continental shelf and oceanic areas.

- Short time intervals - Carrying out collections at intervals of hours, days or weeks is a priority for the study of zooplankton temporal variation, for these scales are more consonant with changes in regional oceanographic and ecological processes. In studies of zooplankton seasonal variation, collections should preferably generate a temporal data series large enough to be analyzed by corresponding statistical techniques (temporal series analysis).

\section{- Zooplankton sampling by Lagrangian methods}

- Drifting sampling along several hours or days, coupled with metabolic and biogeochemical studies, represent a powerful tool for the study of zooplankton temporal succession in relation to shortterm environmental changes.

- Intensification of oceanographic campaigns in less-studied areas - This is an urgent need off the entire Brazilian coast north of the Abrolhos Reefs, and over the continental shelf off the states of Paraná and Santa Catarina. The same applies to the oceanic areas over the entire Brazilian continental shelf, especially relating to the knowledge of bentho-pelagic interactions and of mesopelagic species, or those that inhabit deeper waters.

- Carrying out studies with those zooplanktonic groups whose distribution is still little known Protozooplankton and meroplankton in general, Cubomedusae and Scyphomedusae, Ctenophora, Turbellaria and pelagic Polychaeta, Ostracoda and Mysidacea, among others, should be targeted in this respect. 
- Sampling on coastal harbor areas subjected to ballast water discharge - This is a high priority problem to be urgently tackled, as the introduction of exotic and harmful species through ballast water has already had impacts on the biodiversity and dynamics of regional coastal ecosystems.

- Experimental approach - Research projects including experiments with dominant zooplankton species and/or size classes should be stimulated, in order to understand trophic interactions, energy flow and production cycles in the pelagic ecosystem. This is an essential step toward modeling efforts of zooplankton-mediated processes, which have been hardly attempted in Brazilian waters (Carbonel and Valentin 1999, Rocha et al. 2003).

- Analysis of environmental covariables relevant to the project objectives - This recommendation obviously applies to all preceding items.

To conclude, it is important to emphasize that the gaps in our knowledge on zooplankton ecology off the Brazilian coast were not pointed out in this brief review to depreciate the results obtained by most research projects carried out to date, which represent the state of the art in this area of biological oceanography. The objectives were, rather, to emphasize that future descriptive studies need to deal with greater spatial and temporal detail, and with taxonomic groups and size classes little studied up to now, as well as to urge that process studies be duly prioritized from here on. These recommendations, if implemented, may significantly contribute to widen the knowledge on biodiversity and ecology of marine zooplankton in Brazil, thus helping to increase the international visibility of our regional and basin-scale investigations.

\section{ACKNOWLEDGMENTS}

The author thanks the support given by Conselho Nacional de Desenvolvimento Científico e Tecnológico (CNPq) (grant \#308055/2004-7). Suggestions given by two anonymous reviewers helped to improve a first version of the manuscript. This paper is dedicated to the memory of Dr. Monica Montú (Fundação Universidade Federal do Rio Grande/FURG), who greatly contributed to the advancement of marine zooplankton research in Brazil until her sudden demise in 2003.

\section{RESUMO}

As pesquisas sobre o zooplâncton marinho no Brasil têm sido primariamente descritivas, com a maioria dos estudos enfocando a análise da estrutura da comunidade e assuntos relacionados. A composição e a distribuição espacial de muitos grupos taxonômicos encontram-se bem estudadas, embora os táxons menos abundantes e de menores dimensões, assim como os estágios iniciais do ciclo de vida da maioria das espécies, tenham recebido pouca atenção. Alguns táxons numericamente importantes encontram-se pouco estudados, como no caso dos protistas heterotróficos, ctenóforos, turbelários acelos e ostrácodes. Amplos setores da plataforma continental não têm sido suficientemente amostrados, em particular nas áreas influenciadas pela Corrente Norte do Brasil $\left(5^{\circ} \mathrm{N}-15^{\circ} \mathrm{S}\right)$. As áreas oceânicas têm sido também pouco estudadas e praticamente inexistem dados sobre a distribuição espacial e vertical das espécies meso- e batipelágicas. Levantamentos faunísticos adicionais devem focalizar os táxons e locais menos conhecidos. No entanto, sob o ponto de vista ecológico é necessário dar prioridade a estudos de processos voltados ao entendimento dos mecanismos que governam a distribuição, as interações tróficas nas teias alimentares pelágicas e os ciclos de produção do zooplâncton em relação ao ambiente físico. Deve ser feito um esforço para incorporar novas tecnologias de amostragem e métodos analíticos em futuros projetos de pesquisa.

Palavras-chave: zooplâncton marinho, ecologia, taxonomia, Atlântico Sudoeste.

\section{REFERENCES}

AlVAREZ MPJ. 1985. Migração vertical de Lucifer faxoni Borradaile, 1915 (Crustacea, Decapoda) nas águas ao largo de Santos, Brasil. Bolm Zool Univ S Paulo 9: 177193.

BERGERON JP. 1995. Aspartate transcarbamylase activity for the assessment of mesozoooplankton production: new aspects from oceanic areas. ICES J Mar Sci 52: 305-313.

BONECKER SLC. 1983. Distribuição da classe Thaliacea (Tunicata) em frente à costa do Estado do Rio de Janeiro. Master's Thesis. Rio de Janeiro, Departamento de Zoologia, Universidade Federal do Rio de Janeiro, RJ, Brasil, $123 \mathrm{p}$.

Bougis P. 1974. Ecologie du plancton marin. II. Le zooplancton. Masson Press, Paris, France. 
BRANDini FP, LOPES RM, GUTSEIT KS, SPACH HL AND SASSI R. 1997. Planctonologia na plataforma continental brasileira. Diagnose e Revisão Bibliográfica. Brasília: Ministério do Meio Ambiente e da Amazônia Legal IBAMA, $196 \mathrm{p}$.

CARBonel C And VALEnTIN JL. 1999. Numerical modelling of phytoplankton bloom in the upwelling ecosystem of Cabo Frio (Brazil). Ecol Model 116: 135-148.

DUCKLOW HW AND STEINBERG DK. 2001. Upper ocean carbon export and the biological pump. Oceanography 14: $50-58$.

ESKINAZI-SANT'ANNA EM. 2006. Sticholonche zanclea (Protozoa, Actinopoda) in fecal pellets of copepods and Euphausia sp. in Brazilian coastal waters. Braz J Biol 66: 839-847.

ESKINAZI-SANT'ANNA EM AND BJÖRNBERG TKS. 2006a. Seasonal dynamics of mesozooplankton in Brazilian coastal waters. Hydrobiol 563: 253-268.

ESKINAZI-SANT'ANNA EM AND BJÖRNBERG TKS. 2006b. Seasonal dynamics of microzooplankton in the São Sebastião Channel, SP, Brazil. Braz J Biol 66: 221231.

Folt C AND Goldman CR. 1981. Allelopathy between zooplankton: a mechanism for interference competition. Science 213: 1133-1135.

FREIRE AS. 2003. Occurrence of decapods larvae, specially Xiphopenaeus kroyeri (Penaeidea) in the shallow shelf of Paraná. Nauplius 10: 37-45.

GAETA SA AND BRANDini FP. 2006. Produção primária do fitoplâncton na região entre o Cabo de São Tomé (RJ) e o Chuí (RS). In: Rossi-Wongtschowski CLDB AND MADUREIRA LS (Eds), O ambiente oceanográfico da plataforma continental e do talude na região sudeste-sul do Brasil, São Paulo, SP, Brasil, EDUSP, p. 219-264.

GOETZE E. 2003. Cryptic speciation on the high seas; global phylogenetics of the copepod family Eucalanidae. Proc Royal Soc London Ser B - Biol Sci 270 (1531): 23212331.

HARBISON GR AND MCALISTER VR. 1980. Fact and artifact in copepod feeding experiments. Limnol Oceanogr 25: 971-981.

HAY S. 1995. Egg production and secondary production of common North Sea copepods: Field estimates with regional and seasonal comparisons. ICES J Mar Sci 52: 315-327.

HIRST AG AND BUNKER AJ. 2003. Growth of marine planktonic copepods: Global rates and patterns in relation to chlorophyll- $a$, temperature, and body weight. Limnol Oceanogr 48: 1988-2010.

HIRST AG AND LAMPITT RS. 1998. Towards a global model of in situ weight-specific growth in marine planktonic copepods. Mar Biol 132: 247-257.

Hopcroft RR, Roff JC AND Chavez FP. 2001. Size paradigms in copepod communities: a re-examination. In: LOPES RM, REID JW AND Rocha CEF (Eds), Copepoda: Developments in Ecology, Biology and Systematics, Dordrecht: Kluwer, p. 133-141.

Huntley M AND Lopez MDG. 1992. Temperature-dependent production of marine copepods: a global synthesis. Am Nat 140: 201-242.

IKEDA T. 1985. Metabolic rates of epipelagic marine zooplankton as a function of body mass and temperature. Mar Biol 85: 1-11.

IKEDA T AND MOTODA S. 1978. Zooplankton production in the Bering Sea calculated from 1956-1970 Oshoro Maru data. Mar Sci Comms 4: 329-346.

IMBER. 2005. Science Plan and Implementation Strategy. IGBP Report 52, Stockholm: IGBP Secretariat, 76 p.

Katsuragawa M, Matsuura Y Suzuki K, Dias JF AND SPACH HL. 1993. O ictioplâncton ao largo de Ubatuba, SP: composição, distribuição e ocorrência sazonal (1985-1988). Publ esp Inst Oceanogr S Paulo 10: 85121.

KIMMERER WJ. 1987. The theory of secondary production calculations for continuously reproducing populations. Limnol Oceanogr 32: 1-13.

Kimmerer WJ AND MCKInNON AD. 1987. Growth, mortality and secondary production of the copepod Acartia tranteri in the Westernport Bay, Australia. Limnol Oceanogr 32: 14-28.

KoettKer AG AND FreIre AS. 2006. The spatial-temporal variation of decapod larvae in the subtropical waters of the Arvoredo Archipelago, SC, Brazil. Iheringia 10: 31-39.

LE BORGNE R. 1982. Zooplankton production in the eastern tropical Atlantic Ocean: net growth efficiency and $\mathrm{P}: \mathrm{B}$ in terms of carbon, nitrogen and phosphorus. Limnol Oceanogr 27: 681-698.

Liang TH AND Vega-Perez LA. 1995. Studies on Chaetognaths off Ubatuba Region, Brazil. II. Feeding habitats. Bolm Inst Oceanogr S Paulo, SP, Brazil 43: 35-48.

LOPES RM AND SILVEIRA M. 1994. Symbiosis between a pelagic flatworm and a dinoflagellate from a tropical area: Structural observations. Hydrobiol 287: 277-284.

Lopes RM, Almeida PRAdo-Por MS AND POR FD. 
1986. Zooplankton seasonality in the Rio Verde Estuary. Rev Hydrobiol trop 19: 207-214.

Lopes RM, BRANDINI FP AND GaETA SA. 1999. Distributional patterns of epipelagic copepods off Rio de Janeiro State, Southeastern Brazil. Hydrobiol 411: 161-174.

Lopes RM, Montú MA, Gorri C, Muxagata E, MiyaSHITA L AND OLIVEIRA LP. 2006a. O zooplâncton marinho da região entre o Cabo de São Tomé (RJ) e o Chuí (RS). In: Rossi-WongtSCHOWsKI CLDB AND MADUREIRA LS (Eds), O ambiente oceanográfico da plataforma continental e do talude na região sudeste-sul do Brasil. São Paulo, SP, EDUSP, p. 265-358.

Lopes RM, Katsuragawa M, Dias J, Montú MA, Muelbert JH, GorRi C AND BRANDini FP. $2006 \mathrm{~b}$. Zooplankton and ichthyoplankton distribution on the southern Brazilian shelf: an overview. Sci Mar 70: 189202.

McManus G, Costas BA, Dam HG, Lopes RM, Gaeta AS, Susini SM and RosetTa CH. 2007. Microzooplankton grazing of phytoplankton in a tropical upwelling region. Hydrobiologia 575: 69-81.

Migotto AE And Marques AC. 2003. Avaliação do estado do conhecimento da diversidade biológica do Brasil Invertebrados marinhos. Brasília: COBIO/MMA - GTB/ CNPq - NEPAM/UNICAMP, 87 p.

Miller CB. 2004. Biological Oceanography. Malden: Blackwell Science, $402 \mathrm{p}$.

MiLls CE. 1995. Medusae, siphonophores, and ctenophores as planktivorous predators in changing global ecosystems. ICES J mar Sci 52: 575-581.

Milstein A. 1979. Vertical distribution of Paracalanus crassirostris (Copepoda, Calanoida): analysis by general linear model. Bolm Inst Oceanogr S Paulo 28: 65-78.

Montú MA AND CORDEIRO TA. 1988. Zooplâncton del complejo estuarial de la Bahía de Paranaguá 1. Composición, dinámica de las especies, ritmos reprodutivos y acción de los factores ambientales sobre la comunidad. Nerítica 3: 61-83.

MOREIRA GS. 1976. Sobre a migração vertical diária do plâncton ao largo de Santos, Estado de São Paulo, Brasil. Bolm Inst Oceanogr S Paulo 25: 55-76.

Moreira GS, Yamashita C AND MCNAMARA JC. 1983. Seasonal variation in abundance of the developmental stages of Euterpina acutifrons (Copepoda: Harpacticoida) from the São Sebastião Channel, southern Brazil. Mar Biol 74: 111-114.

MuXagata E. 1999. Avaliação da biomassa e distribuição zooplanctônica na plataforma continental Sudeste Brasi- leira durante o inverno de 1995. Master's thesis, Rio Grande: Fundação Universidade Federal do Rio Grande, $176 \mathrm{p}$.

NAVAS-Pereira D. 1973. Análise qualitativa e quantitativa do zooplâncton. Publ esp Inst Oceanogr S Paulo, SP, Brasil 3: 29-92.

Oliveira OMP And Migotto AE. 2006. Pelagic ctenophores from the São Sebastião Channel, southeastern Brazil. Zootaxa 1183: 1-26.

OOSTERHUIS SS, BAARs MA AND KLEIN BRETELER WCM. 2000. Release of the enzyme chitobiase by the copepod Temora longicornis: characteristics and potential tool for estimating crustacean biomass production in the sea. Mar Ecol Prog Ser 196: 195-206.

PERRY RI AND OMMER RE. 2003. Scale issues in marine ecosystems and human interactions. Fish Oceanogr 12: 513-522.

PINESE JF. 1982. Distribuição vertical e variação sazonal de Acartia lilljeborgi (Copepoda, Calanoidea) na enseada do Flamengo - Ubatuba. Master's Thesis, São Paulo: Instituto Oceanográfico, Universidade de São Paulo, 55 p.

Poulet AS, IANora A, LAabir M ANd Klein BreteLER WCM. 1995. Towards the measurement of secondary production and recruitment in copepods. ICES J Mar Sci 52: $359-368$.

Rigler FH AND Downing JA. 1984. The calculation of secondary production. In: DowNING JA AND RIGLER FH (Eds), Manual on methods for the assessment of secondary production in fresh waters, Oxford: Blackwell, p. $19-58$.

RochA CEF. 1982. Distribution of the marine cladocerans (Crustacea, Branchiopoda) off Santos, Brazil. Bolm Zool Universidade de São Paulo 7: 155-169.

Rocha CEF. 1983. Distribution of Euconchoecia chierchiae G.W. Muller (Crustacea, Ostracoda) off Santos, Brazil. Bolm Inst Oceanogr S Paulo 6: 53-61.

Rocha GRA, Rossi-Wongtschowski CLDB, PIRESVANIN AMS AND JARRE-TEICHMANN A. 2003. Seasonal budgets of organic matter in the Ubatuba shelf system, SE Brazil. I. Planktonic and benthic components. Ocean Acta 26: 487-495.

Roff JC, Kroetsch JT AND Clarke AJ. 1994. A radiochemical method for secondary production in planktonic crustacea based on the rate of chitin synthesis. J Plankt Res 16: 961-976.

Roman MR AND Rubble PA. 1980. Containment effects in copepod grazing experiments: A plea to end the black box approach. Limnol Oceanogr 25: 982-990. 
SAiz E, CAlbet A, FAra A AND Berdalet E. 1998. RNA content of copepods as a tool for determining adult growth rates in the field. Limnol Oceanogr 43: 465-470.

SAPIENZA C AND MAgUe TH. 1979. DNA polymerase activity and growth rates in Artemia salina nauplii. Limnol Oceanogr 24: 572-576.

SARTORI LP AND LOPES RM. 2000. Seasonal variability of pelagic copepod assemblages on the inner continental shelf off Paraná, Brazil. Náuplius 8: 79-88.

SCHWAMBORN R AND BONECKER ACT. 1996. Seasonal changes in the transport and distribution of meroplancton into a Brazilian estuary with emphasis on the importance of floating mangrove leaves. Arq Biol Tecnol 39: 451462.

SINQUE C. 1983. Distribuição vertical de Appendicularia (Tunicata) ao largo de Santos, Brasil $\left(24^{\circ} 16^{\prime} 08^{\prime \prime} \mathrm{S}\right.$ e $\left.46^{\circ} 00^{\prime} 04^{\prime \prime} \mathrm{W}\right)$. Arq Biol Tecnol 26: 61-76.

SUSINI-RIBEIRO SMM. 1999. Biomass distribution of pico-, nano- and microplankton on the continental shelf of Abrolhos, East Brazil. Arch Fish Mar Res 47: 271-284.

TAVARES DQ. 1967. Occurrence of doliolids and salps during 1958, 1959 and 1960 off the São Paulo coast. Bolm Inst Oceanogr S Paulo 16: 87-97.
Teixeira C And Gaeta SA. 1991. Contribution of picoplankton to primary production in estuarine, coastal and equatorial waters of Brazil. Hydrobiol 209: 117-122.

VALENTIN JL. 1980. L'écosystème d'upwelling à Cabo Frio (Brésil). Analyse en composantes principales du plancton à une station fixe. Ocean. Acta 3 : 43-50.

VALENTIN JL. 1984. Spatial structure of the zooplankton community in the Cabo Frio region (Brazil) influenced by coastal upwelling. Hydrobiol 113: 183-199.

VALENTIN JL. 1989. A dinâmica do plâncton na ressurgência de Cabo Frio - RJ. In: BRANDInI FP (Ed), Memórias do III Encontro Brasileiro de Plâncton, Caiobá: Editora da Universidade Federal do Paraná, p. 26-35.

Valentin JL, Monteiro-Ribas MA, Mureb E And PESSOTI E. 1987. Sur quelques zooplanctontes abondants dans l'upwelling de Cabo Frio (Brésil). J Plankt Res 9: 1195-1226.

Veloso VG AND VALENTIN JL. 1993. Larval distribution and seasonal abundance of Emerita brasiliensis Schimitt, 1935 (Decapoda, Hippidae) in southern Brazil. Rev Bras Biol 53: 131-141. 